\title{
HUBUNGAN LAMA KERJA DENGAN PAPARAN TIMBAL (PB) DALAM URINE PADA OPERATOR PERCETAKAN DI PT MANADO PERSADA MADANI
}

\section{LONG STANDING RELATIONSHIP WITH LEAD (PB) EXPOSURE IN URINE AT PT MANADO PERSADA MADANI}

\author{
Abraham Momongan, ${ }^{\text {a) }}$ Agus Rokot, ${ }^{\text {b) }}$ Agnes T. Watung ${ }^{\text {b) }}$ \\ a) Puskesmas Tumpaan Minahasa Selatan Indonesia \\ b) Jurusan Kesehatan Lingkungan Poltekkes Kemenkes Manado Indonesia \\ Email : abram27momongan@gmail.com
}

\begin{abstract}
Lead $(\mathrm{Pb})$ is a heavy metal that is naturally present in the earth's crust and is spread through natural processes and comes from various human activities.Increased levels of $\mathrm{Pb}$ in the air as well as the working enviroment and industrial waste that uses Pb. Printing operators or employees are one of the groups exposed to lead $(\mathrm{Pb})$. The purpose of this study was to determine the relationship of work duration with lead exposure $(\mathrm{Pb})$ in urine on printing operator at PT Manado Persada Madani. This research is a quantitative study using observational analytic methods with cross sectional design. The sample in this study were all workers who served as printing operators, in sampling using cluster sampling techniques as many as 13 people by using two treatment of sampling namely before work and after work.Bivariate analysis research results were analyzed using the non parametric correlations test proving that there is a significant relationship between length of work with lead levels in printing operators with a correlation value $=0,852$ with a strong correlation category. Statistically prove that there is a significant relationship between the length of work with lead levels in urine in printing operators who obtain $P=1,000$ values.
\end{abstract}

Key word : Work time, lead, printing operators

\begin{abstract}
ABSTRAK
Perkembanganan industrilisasi dan teknologi makin banyak bahan dan alat yang digunakan mempunyai resiko terhadap kesehatan, salah satunya adalah operator percetakan yang sering terpaparnya timbal $(\mathrm{Pb})$. Penelitian ini untuk mengetahui hubungan lama kerja dengan paparan timbal $(\mathrm{Pb})$ dalam urine pada operator percetakan di PT Manado Persada Madani. Penelitian ini merupakan penelitian secara kuantitatif dengan menggunakan metode analitik observasional dengan desain cross sectional. Sampel pada penelitian ini seluruh pekerja yang bertugas sebagai operator percetakan, dalam pengambilan sampel menggunakan teknik cluster Sampling sebanyak 13 orang dengan menggunakan 2 kali perlakuan pengambilan sampel yakni sebelum bekerja dan sesudah bekerja. Hasil penelitian analisis bivariat yang dianalisis dengan menggunakan uji parametric correlations, membuktikan bahwa ada hubungan yang bermakna antara lama kerja dengan kadar timbal pada operator percetakan dengan nilai korelasi $=0,852$ dengan kategori korelasi yang sangat kuat. Secara statistik membuktikan bahwa ada hubungan yang bermakna antara lama kerja dengan kadar timbal dalam urine pada operator percetakan yang memperoleh nilai $p=1,000$.
\end{abstract}

Kata Kunci: Lama Kerja ; Timbal ; Operator Percetakan.

\section{LATAR BELAKANG}

Paparan $\mathrm{Pb}$ yang berlangsung lama dapat mengakibatkan gangguan terhadap berbagai sistem organ seperti darah, sistem saraf, ginjal, sistem mereproduksi dan saluran cerna(Manahan, 1992) ${ }^{1}$
Timbal sering ditemukan pada industri cat, Industri perpipaan, industri pengelolaan logam, Industri baterei, pabrik marmer, indutri keramik, dan industri percetakan, pada industri percetakan tinta yang sering digunakan yaitu timbal jenis ionorganik yang biasa digunakan untuk tambahan pada tinta cetak dengan tujuan 
untuk melekatkan warna cetak dan memperkuat kualitas warna. Jenis $\mathrm{Pb}$ Sulfat dan $\mathrm{Pb}$ karbonat yang digunakan sebagai tambahan warna putih, $\mathrm{Pb}$ kromat sebagai tambahan warna kuning, jingga, merah dan hijau ( Sripathy dkk, 2014). ${ }^{2}$

Urin atau air kencing merupakan salah satu sisa metabolisme tubuh yang dapat memberikan gambaran keadaan kesehatan tubuh kita. Pemeriksaan urin bisa memberikan gambaran tentang fungsi ginjal, saluran kemih baik atas maupun bagian bawah, fungsi hati, infeksi pada saluran kemih dan lain-lain. Pemeriksaan ini merupakan pemeriksaan yang paling dianjurkan sebagai screening test pada keracunan timbal. Kadar timbal dalam urine juga bisa membantu menegakkan diagnosis, ketika kadarnya diatas $0,02 \mu \mathrm{g} / \mathrm{dL}$ dianggap sudah cukup bermakna untuk diagnosis keracunan timbal (Permatasari, 2012) ${ }^{3}$

Efek timbal pada sistem urinia dimana senyawa timbal yang terlarut dalam darah akan dibawah keseluruh tubuh, darah akan terus masuk ke glomerulus yang merupakan bagian dari ginjal. Dalam glomerulus terjadi proses pemisahan akhir dari semua bahan yang dibawah darah. Ikut sertanya senyawa $\mathrm{Pb}$ yang terlarut dalam darah dapat mengakibatkan terjadi kerusakan pada saluran ginjal. Kerusakan yang terjadi tersebut disebabkan terbentuknya intranuclear inclusion bodies yang disertai dengan membentuknya aminociduria yaitu terjadinya kelebihan asam amino dalam urin. Aminociduria dapat kembali normal setelah selang waktu beberapa minggu tetapi intranuclear inclucion bodies membutuhkan waktu bertahun-tahun untuk kembali normal. (Chandha. P.V. 1995) ${ }^{4}$

Prosentase komposisi bahan-bahan produksi tinta cetak terdiri dari Pigmen 1525\% (Organik Pigmen dan anorganik Pigmen), Varnish 55-80\%, Solvent 5-10\%. (Muryeti, 2008) ${ }^{5}$ Consumer Product Safety Commission (CPSC) menyebutkan NAB timbal dalam tinta adalah $600 \mathrm{ppm}$ atau $0,06 \%$ dari berat kering tinta (ATSDR, 2007). Menurut Kepmenkes No: 1406/Menkes/SK/XI/2002 ${ }^{6}$ tentang Standar Pemeriksaan Timah Hitam pada Spesimen Biomarker Manusia menyatakan kadar timah hitam dalam urin $150 \mu \mathrm{g} / \mathrm{ml}$ Creatinin. ( Kepmenkes 1406, 2002)

Hasil penelitian sebelumnya yang di lakukan oleh (Yunaska, 2013) ${ }_{7}$ Pada penelitian limbah cair industri percetakan secara elektrolisis, limbah yang dihasilkan dari C.V. Prima Puspa Sari mengunakan tinta Cemani Toka menghasilkan kandungan logam berat $\mathrm{Pb}$ dengan konsentrasi logam berat sebesar 35,09 $\mathrm{mg} / \mathrm{L}$ adalah urutan paling tinggi. Regulasi yang mendukung didasarkan pada Peraturan Menteri Lingkungan Hidup no 5 tahun $2014^{8}$ tentang Baku Mutu Air Limbah maka unsur logam berat Timbal pada Perusahaan yang belum tercantum dalam baku mutu kategori II dipersyaratkan $\mathrm{Pb} 1 \mathrm{mg} / \mathrm{L}$. (PerMenLH, 2014)

Pengamatan langsung pada survei awal yang telah dilakukan oleh peneliti ada beberapa proses aktivitas yang dapat membuat pekerja terpapar dengan timbal baik secara inhalasi serta kontak kulit dengan bahan baku sumber paparan. Salah satu adalah menggunakan merek tinta yang sama dipakai oleh percetakan PT Manado Persada Madani. Berdasarkan hasil penelitian yang disadur dari jurnal diatas dimana tinta percetakan dapat memberikan paparan kandungan Timbal yang di hubungkan dengan lama kerja mempengaruhi kadar timbal dalam urine.

\section{BAHAN DAN METODE}

Penelitian ini merupakan penelitian secara kuantitatif dengan menggunakan metode analitik observasional dengan desain cross sectional karena pada penelitian ini variabel independen dan dependen diamati secara bersamaan. Prosedur Kerja (menurut Association of Official Analytical Chemists)

Ruangan Computer to Plate adalah tempat memindahkan materi berita atau iklan pada lembaran plate untuk dimasukan pada roller mesin cetak, ruangan pencucian plate terdapat banyak zat kimia yang bersenyawa mudah terhirup ketika berada dalam ruangan ini. 
Tabel 1. Distribusi Paparan Timbal (Pb) Dalam Urine Pada Operator Percetakan Di PT Manado Persada Madani Tahun 2019

\begin{tabular}{cccccc}
\hline No. & Kadar Pb Dalam Urine & \multicolumn{2}{l}{ Jumlah Sampel } & $\begin{array}{c}\text { Banyaknya } \\
\text { A + B }\end{array}$ & Persentase (\%) \\
\hline 1 & A & B & & 53,85 \\
2 & $\begin{array}{c}<\text { Nilai Ambang Batas } \\
(<0,15 \mathrm{mg} / \mathrm{l}) / \text { MS } \\
>\end{array}$ & 7 & 7 & 14 & 46,15 \\
& Nilai Ambang Batas \\
$(>0,15 \mathrm{mg} / \mathrm{l}) / \mathrm{TMS}$ & 6 & 6 & 12 & 100,00
\end{tabular}

\begin{tabular}{ll}
\hline Keterangan : $\mathrm{A}=$ Sebelum Bekerja $\mathrm{B}=$ Sesudah Bekerja \\
Tabel 1 diperoleh hasil pemeriksaan & pada waktu subuh. Hasil pemeriksaan \\
kadar timbal $(\mathrm{Pb})$ dalam urine Operator & Nilai Ambang Batas <0,15 mg/l \\
Percetakan di PT Manado Persada & berjumlah 12 sampel atau 6 orang \\
Madani dilakukan 2 kali pengambilan & $(46.15 \%)$. Sedangkan melebihi Nilai \\
sampel, yakni perlakuan mengambil & Ambang Batas $>0,15 \mathrm{mg} / \mathrm{l}$ berjumlah 7 \\
sampel sebelum bekerja pada malam & orang atau 14 sampel $(53.85 \%)$.
\end{tabular}
hari dan setelah selesai beraktivitas

Tabel 2. Hasil Pemeriksaan Paparan Timbal $(\mathrm{Pb})$ Dalam Urine Pada Operator Percetakan Di PT Manado Persada Madani Tahun 2019

\begin{tabular}{|c|c|c|c|c|}
\hline No & Nama Sampel & Hasil Sebelum Bekerja (A) & Hasil Sesudah Bekerja (B) & Persyaratan \\
\hline 1 & Sampel 1 & $0.09 \mathrm{mg} / \mathrm{l}$ & $0.10 \mathrm{mg} / \mathrm{l}$ & MS \\
\hline 2 & Sampel 2 & $0.39 \mathrm{mg} / \mathrm{l}$ & $0.38 \mathrm{mg} / \mathrm{l}$ & $T M S$ \\
\hline 3 & Sampel 3 & $0.45 \mathrm{mg} / \mathrm{l}$ & $0.46 \mathrm{mg} / \mathrm{l}$ & $T M S$ \\
\hline 4 & Sampel 4 & $0.10 \mathrm{mg} / \mathrm{l}$ & $0.10 \mathrm{mg} / \mathrm{l}$ & MS \\
\hline 5 & Sampel 5 & $0.12 \mathrm{mg} / \mathrm{l}$ & $0.12 \mathrm{mg} / \mathrm{l}$ & MS \\
\hline 6 & Sampel 6 & $0.20 \mathrm{mg} / \mathrm{l}$ & $0.16 \mathrm{mg} / \mathrm{l}$ & $T M S$ \\
\hline 7 & Sampel 7 & $0.32 \mathrm{mg} / \mathrm{l}$ & $0.33 \mathrm{mg} / \mathrm{l}$ & $T M S$ \\
\hline 8 & Sampel 8 & $0.15 \mathrm{mg} / \mathrm{l}$ & $0.13 \mathrm{mg} / 1$ & MS \\
\hline 9 & Sampel 9 & $0.06 \mathrm{mg} / \mathrm{l}$ & $0.06 \mathrm{mg} / \mathrm{l}$ & MS \\
\hline 10 & Sampel 10 & $0.10 \mathrm{mg} / \mathrm{l}$ & $0.06 \mathrm{mg} / \mathrm{l}$ & MS \\
\hline 11 & Sampel 11 & $0.40 \mathrm{mg} / \mathrm{l}$ & $0.41 \mathrm{mg} / \mathrm{l}$ & $T M S$ \\
\hline 12 & Sampel 12 & $0.48 \mathrm{mg} / \mathrm{l}$ & $0.43 \mathrm{mg} / \mathrm{l}$ & $T M S$ \\
\hline 13 & Sampel 13 & $0.13 \mathrm{mg} / \mathrm{l}$ & $0.12 \mathrm{mg} / \mathrm{l}$ & MS \\
\hline
\end{tabular}

Tabel 2 diperoleh hasil pemeriksaan paparan timbal $(\mathrm{Pb})$ dalam urine Operator Percetakan di PT Manado Persada Madani telah dilakukan dua kali perlakuan pengambilan sampel, yakni perlakuan mengambil sampel urine sebelum bekerja pada malam hari dan pengambilan sampel urine setelah selesai melakukan pekerjaan pada waktu subuh. sDikatakan memiliki hubungan yang signifikan jika nilai $p>0,05$ dan 
sebaliknya hubungan sangat lemah jika nilai $\mathrm{p}$ $<0,05$.

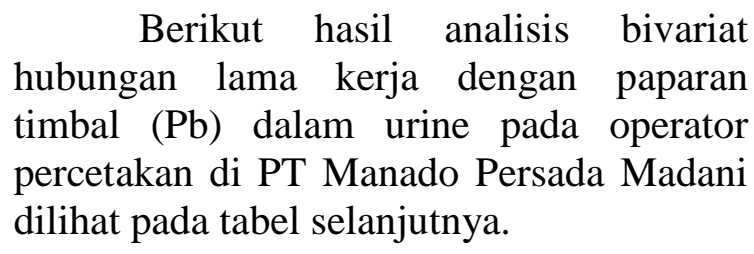

\section{PEMBAHASAN}

Lama kerja/waktu kerja bagi seseorang menentukan efisiensi dan produktivitasnya. Lamanya seorang bekerja sehari baik pada umumnya 6-8 jam. Dalam seminggu orang hanya bisa bekerja dengan baik selama 40-50 jam. Lebih dari itu kecenderungan timbulnya hal-hal yang negatif. Makin panjang waktu kerja, makin besar kemungkinan terjadinya halhal yang tidak di inginkan. Jumlah 40 jam kerja seminggu ini dapat dibuat 5 atau 6 hari kerja tergantung pada berbagai faktor (Suma'mur, 2013).

\section{Operator percetakan rata-rata} melakukan aktivitas mereka selama 6 jam/hari. Waktu mereka lebih banyak menunggu materi berita dan iklan masuk di ruang CTP dengan menunggu di areal percetakan dimana banyak bahan-bahan kontaminan yang dibiarkan berserakan. Ada beberapa operator yang datang lebih awal menghabiskan waktu untuk tidur sambil menunggu dimulai persiapan mencetak koran.

Penelitian yang telah dilakukan dari 2 kali perlakuan pengambilan sampel sebelum bekerja pada jam 9-10 malam, kemudian dilanjutkan pengambilan sampel kedua pada subuh antar ajam 4-5 subuh, Hasil penelitian diolah dengan uji korelasi menunjukan tidak ada hubungan antara kadar timbal setelah bekerja dimana nilai $\mathrm{p}=0,000$. (lihat pada tabel 11) Hasil yang diperoleh dapat diinterpretasikan bahwa paparan timbal rentang waktu pendek (6 jam) belum menunjukan adanya paparan yang bermakna atau nilai yang diperoleh sangat lemah.

Hasil analsis uji korelasi pada tabel 11 yang sama dikaitkan dengan lama kerja menunjukan adanya korelasi yang sangat kuat dimana nilai $p=1,000$ yang menandakan kadar timbal dalam urine mempunyai korelasi akan hubungan lama kerja pada operator percetakan di PT Manado Persada Madani. Hasil penelitian sejalan dengan kadar timbal dalam darah pada tenaga kerja yang bekerja di flux dan mesin percetakan penelitian yang dilakukan oleh Sripathy, L ( Journal, 2014) ${ }^{2}$. Tujuan utama dari jurnal ini adalah untuk menentukan tingkat kadar timbal dalam darah dari karyawan yang bekerja di flux dan mesin cetak. Laporan analisa dari bentuk grafik. Tingkatan $\mathrm{Pb}$ berkisar dari 8.3 sampai 14.7 (fig-1) dalam industri flux dan 7,3 sampai 12,6 (fig-2), ternyata dalam perusahaan percetakan berkorelasi dengan nilai kontrol ( fig-3). Ditemukan bahwa ada kadar timbal dalam darah normal.

Lama kerja merupakan lamanya responden bekerja sebagai operator percetakan di PT Manado Persada Madani Berdasarkan pada tabel 3 dapat dilihat bahwa 46,05\% sampel bekerja lebih dari < 5 tahun berjumlah 6 tahun adalah tertinggi. Terdapat selisih tahun bekerja lebar antara operator bekerja Ini menunjukkan bahwa tingkat risiko paparan $\mathrm{Pb}$ pada operator percetakan lama sangat rentan di PT Manado Persada Madani. Berdasarkan pada data primer ( dari manajemen perusahaan ) dan sekunder yang diperoleh peneliti, faktor pengalaman serta keahlian dalam menghasilkan kualitas produk cetakan koran, perawatan mesin secara rutin mesin percetakan sehingga beberapa operator yang mempunyai masa kerja panjang mempunyai posisi strategis dalam perusahaan. Operator percetakan dengan jumlah tahun bekerja lama masih tetap turun lansung mengawasi bahkan turun langsung dalam bekerja. Lama kerja memungkinkan akumulasi timbal dalam urine juga meningkat karena telah lama terjadi kontak kulit yang telah terkontaminasi pada saat memasukan tinta atau pada saat pemeliharaan mesin-mesin percetakan. Pekerja percetakan dalam kegiatannya bisa mendapatkan hasil untuk melihat ada hubungan lama kerja dalam rentang waktu sehari timbal dalam tinta cetak dapat masuk ke dalam tubuh manusia melalui absorpsi kulit dan ingesti atau hand to mouth apabila pekerja tidak menjaga higiene dan sanitasi selama bekerja (Oke, dkk, 2008) ${ }^{11}$

Berdasarkan tabel 10 distribusi paparan kadar $\mathrm{Pb}$ dalam urine operator percetakan yang jika dibandingkan dengan nilai standar 
(Workplace Exposure Standards and Biological Exposure Indices) yaitu $<150 \mu \mathrm{g} / \mathrm{L}$ atau $<0,15 \mathrm{mg} / \mathrm{L}$ maka 7 orang $(53,85 \%)$ memenusi syarat tidak melebihi Nilai Ambang Batas (NAB) serta terdapat tidak memenuhi syarat dan 6 orang $(46,15 \%)$ di bawah Nilai Ambang Batas (NAB) atau memenuhi syarat. Hasil pemeriksaan menunjukan kadar urine pada pekerja percetakan telah ada dalam urine mereka, meskipun pada kategori yang memenuhi syarat nilai ambang batas. Menurut jurnal yang dibuat oleh Humairo (2017) ${ }^{12}$ tidak selaras bahwa disimpulkan kadar timbal dalam darah pada pekerja percetakan unipress masih dalam batas normal.

Hasil pemeriksaan dilaboratorium jurusan analis kesehatan menunjukan karakteristik kekeruhan sampel mempengaruhi kandungan timbal yang ada pada urine, sementara ukuran $\mathrm{pH}$ bervariasi dari asam sampai basa bisa dilakukan penyesuaian dengan penambahan larutan asam nitrat ataupun laruan amonia sampai didapat $\mathrm{pH}$ dengan ukuran 6. Peneliti melakukan pemeriksaan 2 kali pada masing-masing sampel. Pada pemeriksaan pertama hasil sampel menunjukan rata-rata angka $<10 \mathrm{ppm}$ pada keseluruhan sampel sehingga dapat dikatakan nilai secara homogen merata

Senyawa-senyawa dalam keadaan basah dapat terarsopsi di dalam media, sehingga kemudian terkontak dengan tangan (Palar, 2004). ${ }^{13}$ Operator percetakan Saat melakukan pekerjaannya pada tabel 8 menunjukan 11 responden $(84,61 \%)$ tidak menggunakan APD dalam aktivitas pekerjaanya sedangkan memakai APD berjumlah 2 responden $(15,39)$. Hal ini di sebabkan karena sarung tangan membuat tidak nyaman saat bekerja. Operator yang menggunakan sarung tangan memakainya dan apabila telah rusak tidak dipakai menunggu di adakan secara mandiri sehingga bisa memakai, hal ini karena kesadaran dari dirinya akan penting penggunaan alat pelindung diri.

Pada umumnya responden tidak mengeluh mengalami sakit apapun, namun melihat kadar $\mathrm{Pb}$ yang tinggi dan sifat $\mathrm{Pb}$ yang kumulatif maka dapat menimbulkan resiko. Toksisitas $\mathrm{Pb}$ akut menandakan gajala-gajala klinis antara lain :
1. Gangguan gastrointestinal, seperti kram perut, kolik, dan biasanya diawali dengan sembelit, mual, muntah-muntah, dan sakit perut yang hebat.

2. Gangguan neurologi berupa ensefalopati seperti sakit kepala, bingung, atau pikiran kacau, sering pingsan atau koma.

3. Gangguan fungsi ginjal, oliguria dan gagal ginjal yang akut bisa berkembang dengan cepat (Widowati dkk, 2008). ${ }^{14}$

Pada tabel 7 dimana operator percetakan dari wawancara yang dilakukan sebagian pekerja merasa tidak merasakan gejala lemah, letih, lesu, lelah, nafsu makan berkurang atau mata berkunang-kunang. Para pekerja berpikir akibat dari siang hari melakukan aktivitas lain di luar kebiasaan orang normal waktu malam harus digunakan untuk tidur dan beristirahat. Kegiatan berpola terbalik bagi pekerja disiasati dengan mengatur jam istirahat sesuai dengan aktifitas dirumah masing masing sehingga bagi pekerja hanya sebagian merasakan gejala-gejala seperti disebutkan diatas.

Operator percetakan di PT Manado Persada Madani keseluruhan pekerja merokok dapat dilihat pada tabel 9. Jenis kelamin dan faktor kebiasaan merokok adalah faktor diduga penyebab kadar timbal telah ada walaupun termasuk dalam kategori memenuhi syarat. Jika dihubungkan pada pekerja kategori kerja lama maka berperan pada masuknya timbal pada tubuh mereka. Adanya perbedaan dalam jurnal (Wirsal Hasan tahun 2013) ${ }^{15}$, menyatakan kadar timbal dalam darah $\mathrm{p}>$ 0,05 terhadap jenis kelamin dan kebiasaan merokok $\mathrm{p}=0,003$.

Upaya untuk mengurangi pencemaran $\mathrm{Pb}$ di lingkungan kerja adalah dengan mengurangi unsur $\mathrm{Pb}$ serta bahan kimia lainnya, yang meliputi :

1. Desain dan tata letak yang adekuat Situasi yang ideal adalah bilamana risiko aspek kesehatan dan keselamatan kerja diperhitungkan sebelum tempat kerja selesai dibuat, seperti pada tahap desain dan tata letak peralatan, serta proses kegiatan di tempat kerja. 
2. Penghilangan atau pengurangan bahanbahan berbahaya pada sumbernya.

Adapun cara - cara yang dilakukan adalah :

a). Penggunaan bahan-bahan yang tidak beracun ( pelarut zat/ bahaya, bahan bakar, bakan baku dan bahan lainnya, hal ini cara yang efektif. Contohnya toluol dan xylol dapat dipakai untuk subtitusi benzene.

b). Cara Isolasi dapat dipakai terhadap zat-zat yang berbahaya untuk mencegah kontak dengan pekerja.

c) Ventilasi ditempat kerja.

Dapat berfungsi untuk suhu yang nyaman serta sirkulasi udara segar, sehingga dapat melarutkan zat-zat pencemar ke tingkat yang diperkenankan.

d) Pemeliharaan dan kebersihan ruang dan peralatan.

3. Pengendalian perorangan

a). Penerapan cara-cara kerja yang baik.

b). Penggunaan alat pelindung perorangan

c) Pembatasan waktu

d) Kebersihan perorangan. (Arif $\mathrm{S}$, 2010) ${ }^{16}$.

Sedangkan untuk penanggulangan toksisitas dan menghindari efek toksik $\mathrm{Pb}$ dapat dilakukan berbagai upaya antara lain :

1. Melakukan tes medis, terutama bagi pekerja yang berisiko terpapar $\mathrm{Pb}$

2. Pemantauan kadar $\mathrm{Pb}$ di udara dan kadar $\mathrm{Pb}$ dalam makanan/minuman secara berkesinambungan

3. Tidak makan, tidak minum, tidak merokok dikawasan tercemar $\mathrm{Pb}$

Solusi bagi operator percetakan yang terpapar kandungan $\mathrm{Pb}$ melewati nilai ambang batas memenuhi syarat sebaiknya banyak mengkomsumsi tahu dan air kelapa muda hijau (Cocos nucifera L), karena makanan dan minuman tersebut dapat menetralisir racun logam berat $\mathrm{Pb}$ yang masuk ke dalam tubuh. Hal ini disebabkan karena tahu dan air kelapa muda mengandung chelating agent, yaitu senyawa yang dapat menyebabkan terjadi proses pengikatan logam. ( Jurnal Chesaria Candra, 2016) ${ }^{17}$.

\section{KESIMPULAN}

Hasil penelitian membuktikan hubungan lama kerja dengan paparan timbal $(\mathrm{Pb})$ dalam urine operator percetakan untuk Lama kerja tertinggi $<5$ tahun dengan jumlah 06 orang $(46,15 \%)$, sedangkan > 11 tahun berjumlah 5 orang $(238,47 \%)$ dengan rata-rata 10.8 tahun kerja. Kadar timbal $(\mathrm{Pb})$ yang diperiksa dalam urine operator pekerja percetakan di PT Manado Persada Madani tahun 2019 adalah sejumlah 13 responden dengan 2 kali perlakuan. Sampel A kadar $\mathrm{Pb}$ terbesar $0,48 \mathrm{mg} / \mathrm{L}$ dan yang terkecil yaitu $0,06 \mathrm{mg} / \mathrm{L}$ dengan kadar rata-rata 0,23 $\mathrm{mg} / \mathrm{L}$. Sampel B kadar $\mathrm{Pb}$ terbesar $0,46 \mathrm{mg} / \mathrm{L}$ dan yang terkecil yaitu $0,06 \mathrm{mg} / \mathrm{L}$ dengan kadar rata-rata $0,22 \mathrm{mg} / \mathrm{L}$. Ada hubungan kuat berkorelasi antara lama kerja dengan paparan kadar timbal pada pekerja percetakan di PT Manado Persada Madani.

\section{DAFTAR PUSTAKA}

1. Manahan, S, E. 1992. Toxicological chemistry, New York : Lewis Publishers.

2. Sripaty, L, Harrprasad, B.N, and Vinaykumar, C (2014) Effect of lead on employees working in flux and Printing Press ,http://rasayanjournal J.Chem Vol 7 no 22 (diakses tanggal 19 November 2018)

3. Permatasari, Shinta. (2012). Studi Kadar Timbal (Pb) Dalam Urine Supir Angkutan Umum. (Skripsi). Fakultas Ilmu Kesehatan UIN Alauddin Makassar. Http://Repositori.UinAlauddin.Ac.Id/3233/1/Shinta\%20perma tasari.Pdf (diakses tanggal 15 November 2018).

4. Chandha, P.V. 1995. Timbal, Ilmu Forensik Dan Toksikologi. Widya Medika. Jakarta.

5. Muryeti, (2008). Ilmu Bahan Grafika: Teknik Grafika \& Penerbitan, Unggul Grafindo. Depok.

6. Keputusan Menteri Kesehatan RI Nomor 1406/Menkes/SK/XI/2002 tentang Standar Pemeriksaan Kadar Timah Hitam Pada Spesimen Biomarker Manusia.

7. Yunaska. W, R. Widodo, D. S, \& Hastuti, R. (2013) Pengolahan Limbah Cair Industri Percetakan Secara Elektrolisis 
Dengan Elektroda Karbon/Karbon. Fakultas Kimia Universitas Diponegoro Semarang,

8. Peraturan Menteri Lingkungan Hidup Republik Indonesia Nomor 5 Tahun 2014 tentang Baku Mutu Air Limbah

9. Azwar, A. Prihatono, J. (2014) Metode Penelitian Kedokteran \& Kesehatan Masyarakat. Binarupa Aksara, Tangerang Selatan.

10. Oke, S.A.,Phillips, T.E., Kolawole, A., Ofiabulu, C.E.,Adeyeye, D.A. (2008). Occupational Lead Exposurein Printing Presses: An Analytical. Approach. The Pacific Journal of Science and technology Vol 91 May-June. Diakses dari

http:/www.akamaiunerversity.us/pjst.ht m 02 Juni 2019)

11. Humairo, M. V. \& Keman S. (2017). Kadar Timbal Darah Dan Keluhan Sistem Syaraf Pusat Pada Pekerja Percetakan Unipress Surabaya. (Jurnal Kesehatan Lingkungan) Vol. 09 No. 1/ Januari
2017: 48-56 (diakses tanggal 18 November 2018).

12. Palar, Heryando. (2004). Pencemaran dan Toksikologi Logam Berat, Rineka Cipta, Jakarta

13. Widowati, Wahyu, Sastiono, Astiana, \& Jusuf, Raymond, R. (2008). Efek Toksik Logam, Andi, Yogyakarta.

14. Wirsal H. Abdul, Abdul R. Matondang.Alvi S (2013) Pengaruh Jenis Kelamin Dan Kebiasaan Merokok Terhadap Kadar Timbal Dalam Darah Universitas Sumatera Utara Semarang, Jurnal FKM Nasional Vol 8, no 4, Tahun 2013 (Diakses tanggal 20 Juni 2019).

15. Arif, S, (2010), Kesehatan lingkungan. Kencana, Jakarta.

16. Chesaria, C., Onny S., Yusniar H.,(2016), Perbedaan Kadar Timbal (Pb) Dalam Darah Sebelum Dan Sesudah Pemberian Air Kelapa Hijau ( Cocos nucifera L) Pada Pekerja \{Pengecatan Di Industri Karoseri Semarang, (Jurnal Kesehatan Masyarakat) Vol. 04 No. 3/ Juli 2016: 732-739 (diakses tanggal 19 Juni 2019). 